国内の実験データに基づいたコンクリートの時間依存性ひずみの予測式 に関する研究 ークリープひずみの予測式一

\title{
STUDY ON THE PREDICTION FORMULA FOR TIME-DEPENDENT STRAIN OF CONCRETE
}

- Prediction formula of total creep strain-

佐 藤嘉昭*1, 清原千鶴*2, 今本啓一*3

寺西浩司*4, 三橋 博三*5, 濱 永康 仁*6

Yoshiaki SATO, Chizuru KIYOHARA, Keiichi IMAMOTO,

Kohji TERANISHI, Hirozo MIHASHI and Yasuhito HAMANAGA

\begin{abstract}
In this paper, the prediction formula of total creep strain of concrete with a normal to high strength concrete was discussed using the test data published in Japan. The proposed model was expressed as the product of two terms; one is the creep parameter that is expressed in terms of the product of four coefficients taking into account of mix proportions, age at loading, relative humidity and the effect of specimen size, the other the time-effect function with no finite limit (logarithmic function). It was found that the proposed prediction formula can estimate the total creep strain more accurately than the other formulas such as JSCE, CEB-FIP1990 and ACI209.
\end{abstract}

Keywords: Total Creep strain, Time-Dependent Strain, Experimental Data, Prediction formula クリープひずみ，時間依存性ひずみ，実験データ，予測式

1.はじめに

コンクリート構造物の収縮ひび割れ対策を確立することはコンク リート工学における古くからの課題であり, コンクリート構造物の 耐久性を向上させ構造物としての性能を長期間維持するという锶点 から，最近，特に注目を集めるようになっている。コンクリート構 造物の収縮ひび割れの予測やひび割れ幅を検討する場合, 部材内に 発生する収縮応力を精度良く算出する必要がある。その際には，コ ンクリートのクリープ特性は極めて重要な要因となることは言うま でもないが，ひび割れ幅を所定の籁囲内に納める，すなわち，ひび 割れ制御設計を実施する場合には，設計施工段階において，コンク リートのクリープひずみを的確に予測することが要求される。

図-1 は, 一定の圧縮荷重あるいは引張荷重（=載荷応力 $\sigma_{0}$ ）を受 けるコンクリート供試体のひずみの経時変化を模式図的にあらわし たものである1)。図中には収縮ひずみ（供試体が乾燥状態にあれば 乾燥収縮ひずみ，密封状態にあれば自己収縮ひずみ）も示されてい る。引張荷重下にある供試体のひずみが引張から圧縮へと移行する 理由は引張荷重によるひずみの進展よりも乾燥収縮や自己収縮によ るひずみの進展のほうがはるかに大きいからである。クリープひず みは, 一般に, 式(1)に示すように, 一定の応力下で測定される全ひ ずみ $\varepsilon$ から載荷直後の弾性ひずみ $\varepsilon_{e}$ 並びに非载荷状態の収縮ひず み $\varepsilon_{s}$ を差し引いたもので表される。クリープひずみの数式表示を行 う場合は, クリープ係数
リープ関数 Jが用いられている。さらに, コンクリートのクリープ は, 供試体と周囲の環境（乾燥条件）との間で水分の移動の無い状 態で得られるひずみを Basic Creepひずみ（密封状態のひずみ），乾

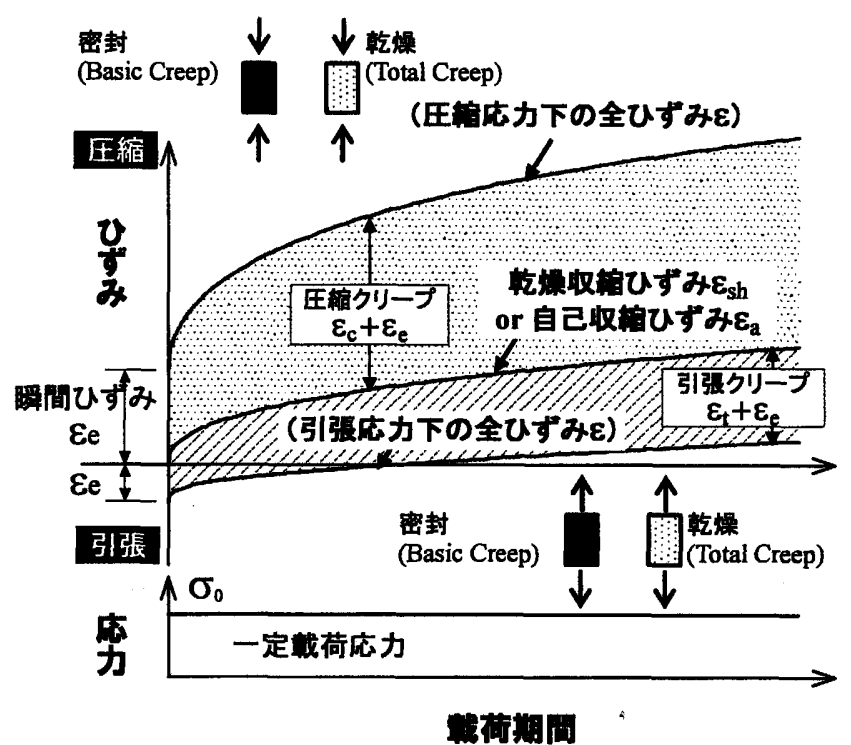

图-1 一定荷重を受ける供試体のひずみと収艏ひずみの経時変化
*1 大分大学工学部福祉環境工学科建築コース 教授・工博

*2 大分大学工学部福祉環境工学科建築コ一ス 助手・工修

*3 足利工業大学工学部建築学科 講師・博士 (工学)

*4 名城大学理工学部建築学科 助教授・博士 (工学)

*5 東北大学大学院工学研究科都市・建築学守攻 教授・工博

*6 大分大学大学院博士後期課程 大学院生 $\cdot$ 工修
Prof., Dept. of Architectural Eng., Faculty of Eng., Oita Univ., Dr. Eng. Research Assoc., Dept. of Architectural Eng., Faculty of Eng., Oita Univ., M. Eng. Lecturer, Dept. of Architecture, Ashikaga Institute of Technology, Dr. Eng. Assoc. Prof., Dept. of Architecture, Faculty of Science \& Technology, Meijo Univ., Dr. Eng.

Prof., Dept. of Architecture and Building Eng., Graduate School of Eng., Tohoku Univ., Dr. Eng.

Graduate Student, Doctor's Course of Architectural Eng., Oita Univ., M. Eng. 


$$
\begin{aligned}
& \varepsilon_{c}=\varepsilon-\varepsilon_{e}-\varepsilon_{s} \\
& \phi\left(t, t_{0}\right)=\frac{\varepsilon_{c}}{\varepsilon_{e}} \\
& C\left(t, t_{0}\right)=\frac{\varepsilon_{c}}{\sigma_{0}} \\
& \left.J\left(t, t_{0}\right)=\frac{\varepsilon_{e}+\varepsilon_{c}}{\sigma_{0}}=\frac{1}{E}+C\left(t, t_{0}\right)=\frac{1}{E}\left\{1+\phi\left(t, t_{0}\right)\right\} \quad\right\} \\
& \text { ここに, } \varepsilon_{c}: \text { クリープひずみ }\left(\times 10^{-6}\right) \\
& \varepsilon \text { : 全測定ひずみ }\left(\times 10^{-6}\right) \\
& \varepsilon_{e}: \text { 瞬間弾性ひずみ }\left(\times 10^{-6}\right) \\
& \varepsilon_{s} \text { ：収樎ひずみ }\left(\times 10^{-6}\right) \\
& \sigma_{0}: \text { 載荷応力 }\left(\mathrm{N} / \mathrm{mm}^{2}\right) \\
& t: \text { 材齢 (日)， } t_{0} \text { : 载荷開始材齢（日） }
\end{aligned}
$$

煤によって付加されるひずみを Drying Creep ひずみと呼び，両者の 和を Total Creep ひずみ（乾燥状態のひずみ）と定義している。

現在，一般に用いられているコンクリートのクリープひずみの予 測式は，主に圧縮応力を載荷した場合のクリープひずみに対して， 調合，材料特性および器境条件などの要因のパラメータで表された ものとなっている。コンクリート構造物に生じる収縮応力を算出す るためには引張応力下のクリープが必要となるが，引張応力下では 測定されるひずみの值が小さく，また，温・湿度などの㻴境条件に
著しく影響を受けることなど実験が困難なため, 引張クリープに関 するデータは著しく少ない。スペシフィッククリープとして表され た圧縮クリープと引張クリープの比較では, 乾燥条件下にある Total Creep の場合，両者はほほ同じ程度の值を示すことが報告されてお り, 一方, 引張クリープのほうが若干大きい結果が示されている場 合も見受けられる。また, 水分の逸散のない Basic Creep では, 引張 クリープの方が小さい值を示す結果が報告されている。このように, 圧縮クリープと引張クリープの差異については必ずしも統一した見 解が得られている状況ではないが ${ }^{2)}$, 引張応力下のクリープ予測式 を構筑するには圧倒的に実験データが少ないことからこここでは圧 縮応力下における害用的なクリープひずみの予測式を検討すること とした。

既往のクリープ予測式におけるパラメータの一覧を表-1 に示す。 何れも圧縮クリープひずみを対象とした予測式である。これによる と CEB-FIP1990 式 ${ }^{3)}, \mathrm{ACI} 209$ 式 ${ }^{4)}$ はクリープ俰数で, 土木学会式 ${ }^{3)}$

\begin{tabular}{|c|c|c|c|c|c|c|c|c|c|c|c|c|c|c|}
\hline & \multirow[b]{2}{*}{$\begin{array}{l}\text { Basic } \\
\text { Drying } \\
\text { の S S } \\
\end{array}$} & \multicolumn{4}{|c|}{ D合の且因 } & \multicolumn{3}{|c|}{ 林斗恃惟 } & \multicolumn{5}{|c|}{ 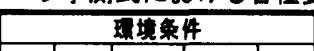 } & \multirow[b]{2}{*}{ 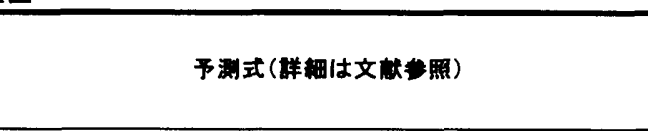 } \\
\hline & & $\begin{array}{l}\text { 水セx } \\
\text { ントt }\end{array}$ & 举位 & 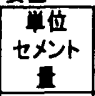 & 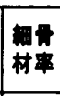 & $\begin{array}{l}\text { スランフ } \\
\text { 空媇 }\end{array}$ & 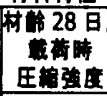 & $\begin{array}{l}\text { セx } \\
\text { rの } \\
\text { 模 } \\
\end{array}$ & $\begin{array}{l}\text { 部材 } \\
\text { 寸法 }\end{array}$ & 温度 & 温度 & 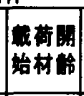 & $\mid \begin{array}{l}\text { 赛生 } \\
\text { 方法 }\end{array}$ & \\
\hline $\begin{array}{c}\text { CEB-FIP } \\
1990^{31}\end{array}$ & 無 & & & & & & $\begin{array}{c}\bigcirc \\
20 \sim 90 \\
\mathrm{~N} / \mathrm{mm}^{2}\end{array}$ & 0 & () & 0 & $\begin{array}{c}\text { O } \\
40 \sim \\
100 \\
\% \text { R.H. }\end{array}$ & 0 & & 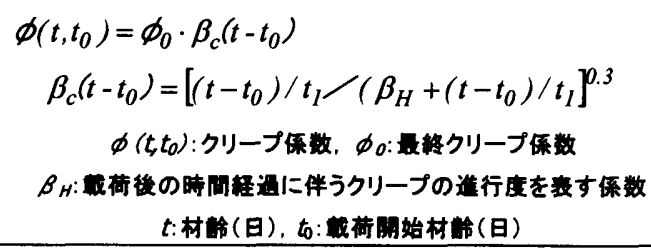 \\
\hline $\mathrm{ACI} 209^{4)}$ & 無 & & & & 0 & $\mathrm{O}$ & & & 0 & & 0 & 0 & 0 & 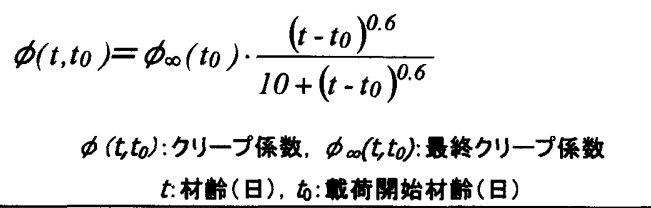 \\
\hline $\begin{array}{c}\text { 土木学会 } \\
\text { 普通強度式 }\end{array}$ & 有 & $\begin{array}{l}O \\
40 \sim \\
65 \%\end{array}$ & $\begin{array}{c}0 \\
130 \sim \\
230 \mathrm{~kg} / \mathrm{m}^{3}\end{array}$ & $\begin{array}{c}O \\
260 \sim \\
500 \mathrm{~kg} / \mathrm{m}^{3}\end{array}$ & & & & & $\begin{array}{c}O \\
\mathrm{~V} / \mathrm{s} \\
100 \\
\sim \\
300 \\
\mathrm{~mm}\end{array}$ & () & $\begin{array}{c}O \\
45 \sim 80 \\
\% R \text { R.H }\end{array}$ & & & 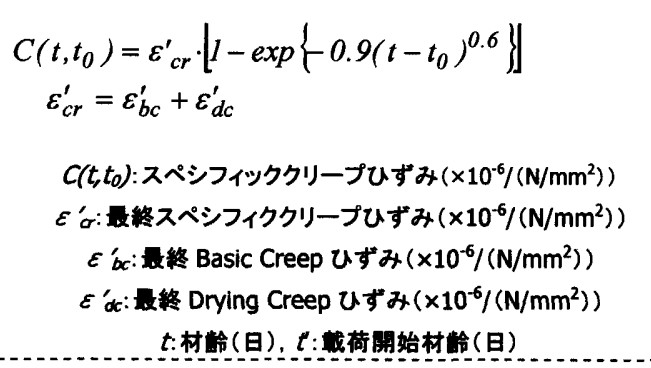 \\
\hline $\begin{array}{l}\text { 土木学会 } \\
\text { 高強度式 }\end{array}$ & 無 & & $\begin{array}{c}\diamond \\
130 \sim \\
230 \mathrm{~kg} / \mathrm{m}^{3}\end{array}$ & & & & $\diamond_{\sim 80}^{\sim}$ & & & $\diamond$ & $\begin{array}{c}\diamond \\
40 \sim 90 \\
\% 6 R . H .\end{array}$ & & & 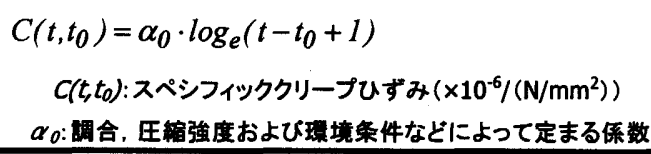 \\
\hline
\end{tabular}
は, スペシフィッククリープひずみで表されており，CEB-FIP1990 式, ACl209 式, 土木学会普通强度式は, 最終值に時間関数を乗じた 形に粠成されているが，土木学会高強度式には最終值が設けられて

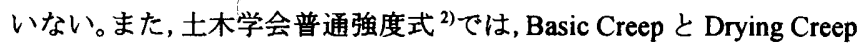
に区別し構成されている。このように国内外において数多くのクリ ープひずみの予测式が提案されているが，これらの精度は $\pm 40 \%$ 程 度であるといった報告 6ももある。ま，日本建築学会においてはク リープひずみの予測式は提案されていないのが現状である。

裹-1 既往のクリープ予測式における各程要因

○：最終值の項に考慮しているパラメータ，@：最終值および時間関数の両方に影響しているパラメータ $\diamond:$ 最終值を持たない関数に属しているパラメータ 
そこで，本研究では，1995 年〜2003 年において日本建築学会を 中心に国内で公表されたコンクリートのクリープひずみに関する実 験データを収集し，国内の寒験データに対する実用的な予測式を構 筑することを目的として収集したデータを分析することとした。な お，本論文におけるクリープひずみとは，供試体が乾燥を受ける状 態で得られる Total Creep ひずみを意味する。

\section{2. 实験データの概要}

本報告で用いた実験データは，日本建築学会学術講演梗概集，日 本コンクリートエ学年次論文集，セメント・コンクリート論文集 (1995〜2003)から収集した 177 件のデータである。その中からクリ ープひずみに関する 1340 データを抽出した。収集した実験データの 概要を図-2に示す。収集した実粡データでは，相対湿度は主に $60 \%$ に分布している。載荷開始材齡は 28 日に集中している。また高強度 コンクリートを対象にして若材龄から載荷した実験データも多い。 調合について見てみると水結合材比は 20〜 60\%の間に幅広く分布し ており，単位水量は $150 \sim 180 \mathrm{~kg} / \mathrm{m}^{3}$ に多く分布している。また材龄 28 日の圧縮強度を見てみると $20 \sim 100 \mathrm{~N} / \mathrm{mm}^{2}$ の間に分布しており， 普通から高強度コンクリートの幅広、範囲のデータであることが分 かる。温度および体積表面積比については，いずれも実験データの

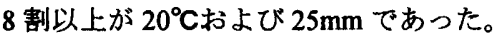

使用材料について着目してみると，セメントの種類においては普 通セメント 129 件, 早強セメント 31 件, 低熱セメント 2 件および高 炉セメント 3 件であった。細骨材の種類においては，川砂 70 件，山 砂 40 件，海砂 19 件および砕砂 11 件であった。粗骨材の種類におい ては, 砕石 123 件，軽量骨材 17 件および砂利 6 件であった。また混 和材を使用したコンクリートにおいても報告されており，使用され
ている混和材の種類は, シリカフューム44 件および高炉スラグ微粉 末 17 件であった。

\section{3.予測式の提案}

\section{1 予㴬式の構成}

クリープひずみと載荷期間の関係を表す場合，すなわち，実験デ 一タに基づいて長期間のクリープひずみを予測する際には, 累乗関 数や対数関数，指数関数，双曲線関数がよく利用されている。累乗 関数は，Bažant ら そによって広く用いられている。双曲線関数およ び指数関数は, Ishai ${ }^{8)}$, Illston"およびRushら ${ }^{10}$ によって用いられて おう，CEB-FIP 式，ACI 式にも採用されている。これらの予測式に は最終值が設けられているのが特徵である。一方，クリープひずみ を成分に分解して，それぞれに式を当てはめる方法がある。クリー プひずみの発生機構については多くの研究者がそれぞれ異なった立 場から理論付けを行っているが，現象を完全に説明できるものがな いのが現状であり，クリープは様々な機構が複雑に組み合わさって 発生していることが指摘されている ${ }^{11)}$ 。水和の進行の影響が小さい 長期材齢のコンクリートの圧縮クリープ実験結果 ${ }^{12}$ によると，コン クリートのクリープひずみは回復性および非回復性の性質を備えて いることが示されている。図-3にクリープひずみの成分の模式図を 示すが，図に示すように，載荷直後は回復性ひずみが大部分を占め ているが時間の経過とともに非回復性のひずみも増加するようにな り，したがって，クリープひずみには最終值は存在せず，载荷期間 が長くなるほどクリープひずみは非回復性ひずみが卓越することと なる。また, コンクリートの含有水分がクリープに及ぼす影響は大 きく, 絶乾状態のコンクリートには載荷直後の遅延弾性によるクリ ープは存在しても，その後クリープは進展しないことが報告されて
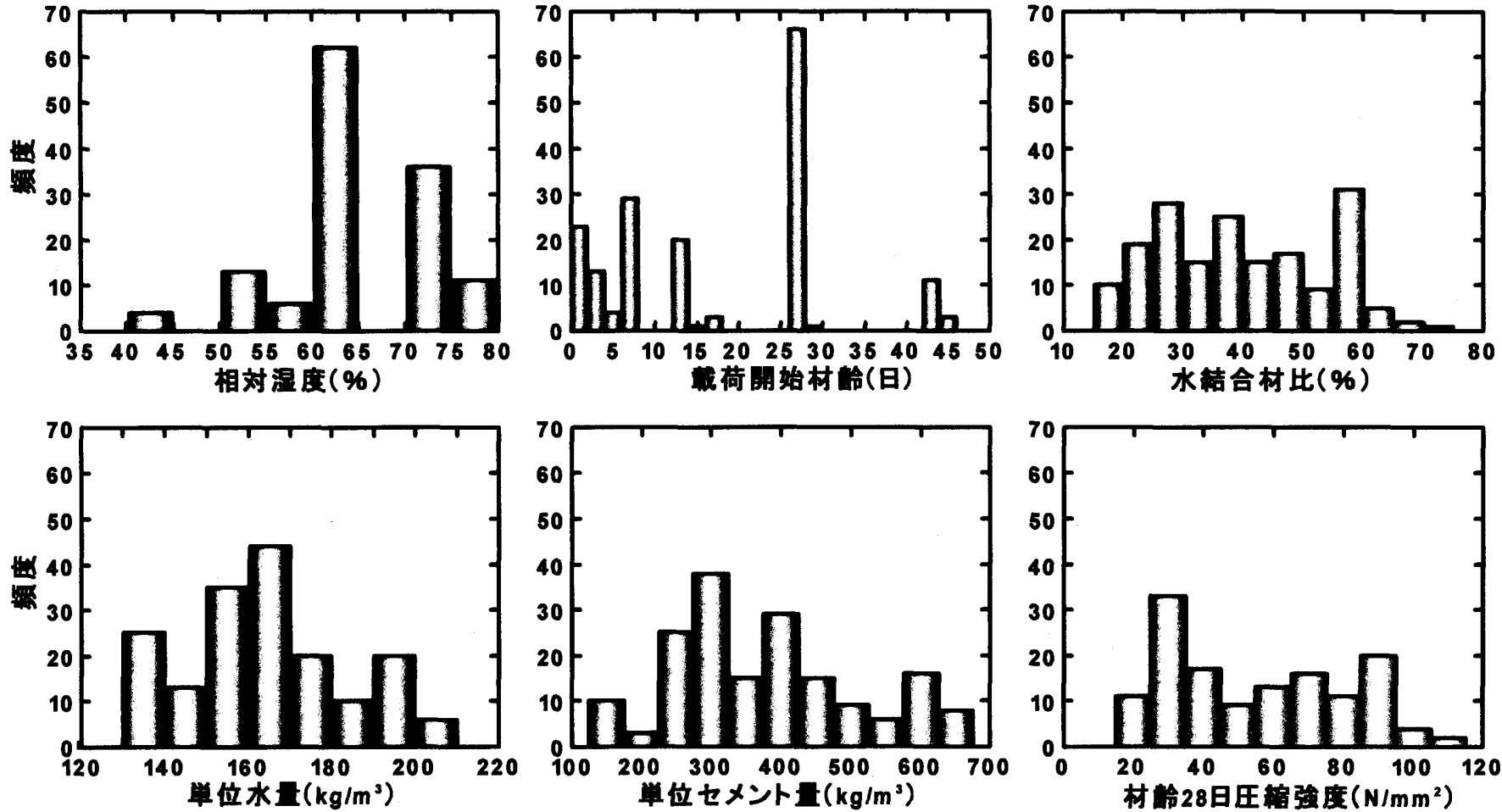

図-2 収集データの概要 


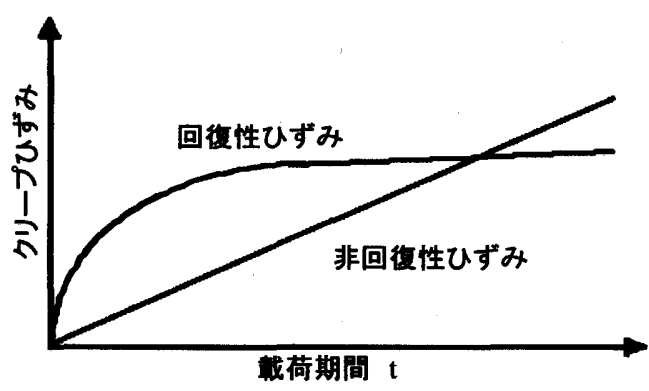

图-3クリープひずみ成分の模式図

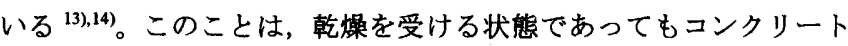
中に水分が存在する限りクリープは進展し続けることを意味してい る。Brooks ら ${ }^{15}$ は，载荷期間 5 年までのクリープひずみに関して, Basic Creep の実験データは累乗関数による表現が, Total Creepにつ いては, 対数の累乗関数が最も適しているように見えるとしている。 また，多くの実験データを回㷌した綾野ら ${ }^{13)}$ の結果からも，クリー プひずみは最終值を持たないとして扱うことが妥当であることが示 されている。

本研究では, 前述したように水分の移動の有無によってクリープ ひずみを分割することは行わず, Basic Creep + Drying Creep であ る Total Creep としての予測式を棧築することにしている。そこで， 本研究で提案するクリープひずみの予測式では, 式(2)に示すように， クリープのメカニズムから判断して最終值を設けず，時間関数とし て対数関数を採用した。時間関数に措かる保数 CR に対しては，収 集した実験データごとに式(2)で近似して係数 CR を求め, 回愑して

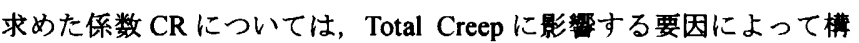
成されるものと仮定し，それらの影警要因として，(1)調合条件によ

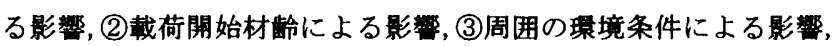
(4)供試体寸法による影敏，を選定した。

$$
\begin{gathered}
C\left(t, t_{0}\right)=C R \cdot \log _{e}\left(t-t_{0}+1\right) \\
C R=K_{1} \cdot K_{2} \cdot K_{3} \cdot K_{4}
\end{gathered}
$$$$
\text { ここに, } \quad C\left(t, t_{0}\right): \text { スペシフィッククリープひずみ }
$$$$
\left(\times 10^{-6} /\left(\mathrm{N} / \mathrm{mm}^{2}\right)\right)
$$$$
C R: \text { 回帰分析により定まる保数 }\left(\times 10^{-6} /\left(\mathrm{N} / \mathrm{mm}^{2}\right)\right)
$$$$
K_{1}: \text { 調合条件による影響に関する俰数 }
$$$$
K_{2}: \text { 载荷開始材齡による影響に関する係数 }
$$$$
K_{3}: \text { 環境条件による影響に関する保数 }
$$$$
K_{4} \text { : 供試体寸法による影響に関する係数 }
$$$$
t: \text { 材齢（日）, } t_{0}: \text { 載荷開始材齢（日） }
$$

\section{2 係数 CR の推定}

式(2)における $K_{1}, K_{2}, K_{3} ， K_{4}$ の算出方法について以下に述べる。

\section{（1）環境条件の影䈏}

図-2に示しているように, 収集した実験データの多くは相対湿度

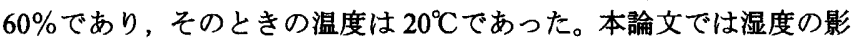
響は，国内の多くの実験データを対象にして構築された阪田式 ${ }^{17}$ に
おける相対湿度の項を参考にし, $60 \%$ R.H.で $K_{3}=1$ となるように決定 した（式(3)参照)。したがって，㻴境条件による影響を表す係数 $\mathrm{K}_{3}$ は, 温度 $20^{\circ} \mathrm{C}$ のとで相対湿度が変動する場合の影響を表している ことになる。

$$
K_{3}=1.4 \cdot\left(1-\frac{h}{100}\right)^{0.36}
$$$$
\text { ここに, } h: \text { 相対湿度 }(\%)
$$

\section{（2）調合の影霬}

普通ボルトランドセメント，天然骨材使用および混和材無混入の 実験デー夕を選定し,載荷開始材齢 28 日並びに供試体寸法が同一条 件のものを対象として調合の影響を表す $K_{1}$ を決定する。そこで，回 㷌して求めた俰数 $C R$ を $K_{3}$ で除した值を $K_{1}$ とした。

ここでは，クリープひずみに影䇾を及ほす拥合条件として，水セ メント比および単位粗骨材量を取り上げ, 目的変数を $K_{1}$, 説明変数

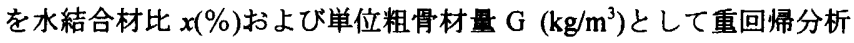
を行った。得られた結果は式(4)のとおりである。なお，水結合材比 とは, セメントおよび混和材を結合材としてみなし，単位水量を単 位結合材で除した値とした。

$$
\begin{aligned}
& K_{I}=0.40 x-0.007 G+1.03 \\
& こ こ に, \quad x: \text { 水結合材比 }(\%) \\
& G: \text { 単位粗骨材量 }\left(\mathrm{kg} / \mathrm{m}^{3}\right)
\end{aligned}
$$

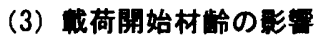

供試体寸法が同一で載荷開始材龄の異なる実験データを選定し， 回㷌して求めた $C R$ を $K_{1}$ と $K_{3}$ で除した值である $K_{2}$ と载荷開始材齢の 関係について求めた。その結果を図-4に示す。図-4より $K_{2}$ のばらつ きは大きいが， $K_{2}$ と载荷開始材齢の影響を式(5)に示す累乗関数で表 すこととした。

$$
K_{2}=3.03 \cdot t_{0}-0.33
$$

$$
\text { ここに, } t_{0}: \text { 載荷開始材齢 }(\text { 日 })
$$

\section{（4）供試体寸法の影墼}

クリープひずみに及ぼす供試体寸法の影響については，一般に， 供試体寸法が大きくなるほど小さくなると言われている。これは次 のように考えられる。供試体が乾燥条件下に置かれた場合，供試体 の表面と内部とでは乾燥の程度が異なることから, 供試体の寸法が 大きいほど, 乾燥の影響が中心部に達するまでには長時間を要する。 このように, 周囲の乾燥条件と平衡状態に達するまでの時間は供試 体寸法が小さくなるほど短くなり，したがって，乾燥の影響による クリープひずみは供試体の寸法が小さいほど大きなひずみを示すこ とになる。

供試体寸法の影響を表すパラメータとして，CEB が使用している 仮想部材厚や土木学会式や ACI が採用している体積表面積比(V/S) などがある。ここでは，供試体の体積を乾燥を受ける表面積で除し 


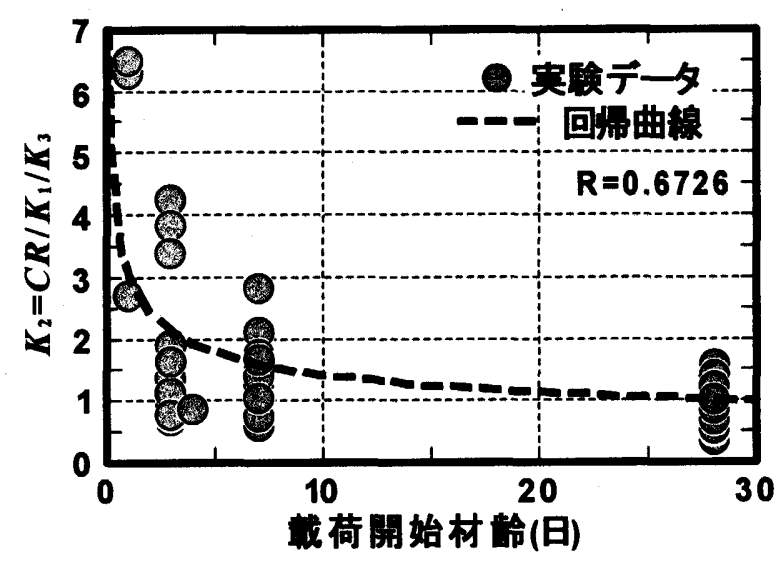

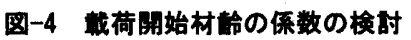

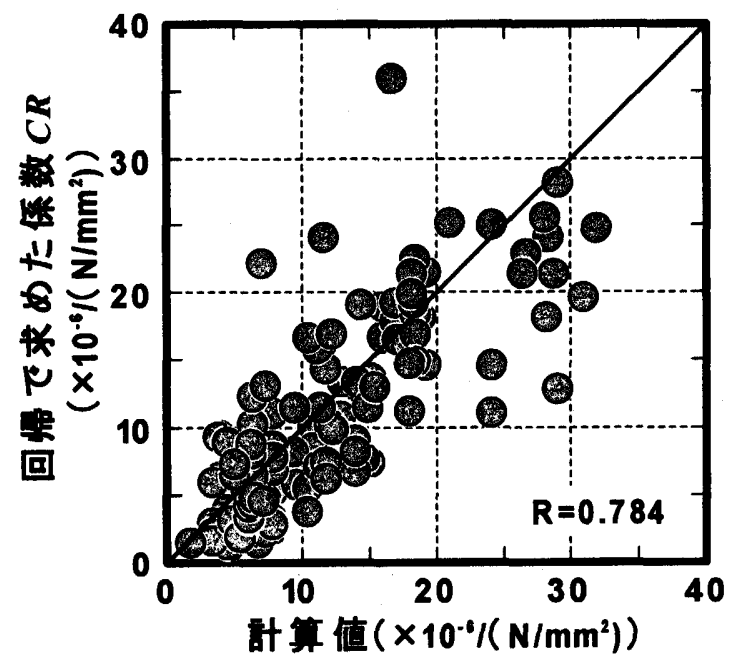

图-6 保数 CRの比較

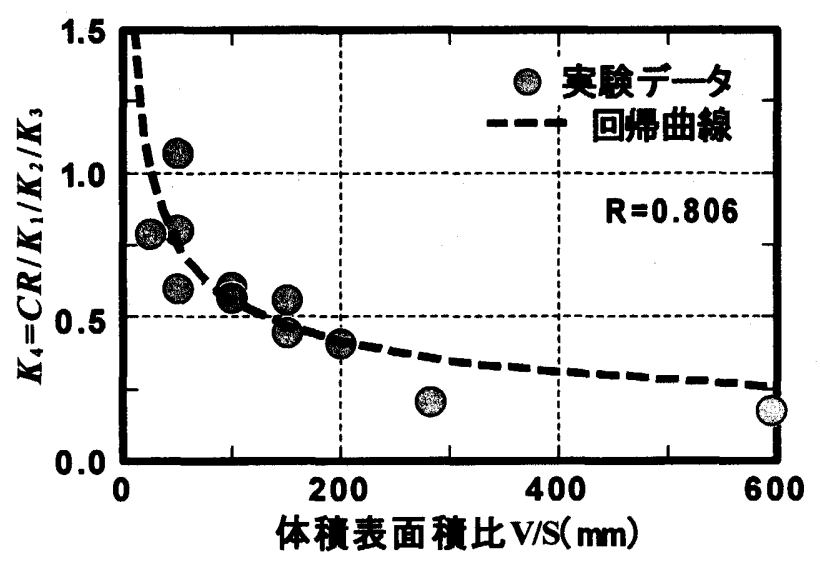

图-5 供组体寸法の係数の検封

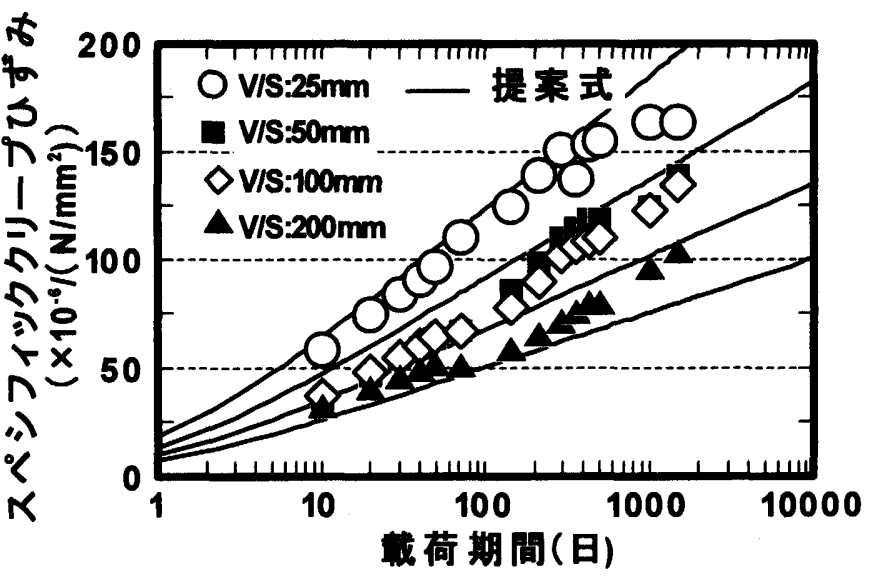

図-7 供结体寸法が舆なる实験データとの比較

大きくなっており，係数 CR に影響する要因が他に存在する可能性 があるが，係数 CR の推定については今後の検討課題としたい。

\section{3 提案式の検証}

提案式を用いてクリープひずみを予測し，既往の実験データと比 較検討を行うこととした。図-7に供試体寸法が異なる実験データ ${ }^{18)}$ の比較を, 図-8に載荷開始材龄が異なる実験データ ${ }^{19}$ の比較を示し ている。図-7 の実験データは水セメント比 0.57 の普通強度コンクリ ートであり，体糟表面積比 V/S は 25，50，100，200 $\mathrm{mm}$ となってい る。図-8 の実䍄データは水セメント比 $0.25 \sim 0.45$ の高強度コンクリ

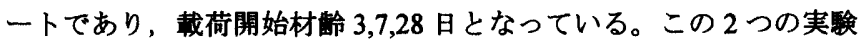
の乾燥条件は温度 $20^{\circ} \mathrm{C}$, 湿度 $60 \%$ R.H.である。これらの図より, 若 干ばらつきはあるものの，予测値は载荷開始材齡および供試体寸法 が異なる実蛤データの㑯向を载荷開始直後からよく表しているもの と思われる。

\section{4. クリープひずみ予洞式の検证}

式(7)の妥当性を確認するために, 式(7)を用いて計算した結果と実 験データより回韧して求めた $\mathrm{CR}$ の関係について調べた。その結果 が図-6である。これによると保数 CR が大きくなるほどばらつきが
本提案式の妥当性を検討するために，収集したデータを用いて， 表-1 に示す土木学会式, CEB-FIP1990 式および ACI209 式との比較 を行った。その結果を図-9に示す。表-1に示すように, 学会などで 

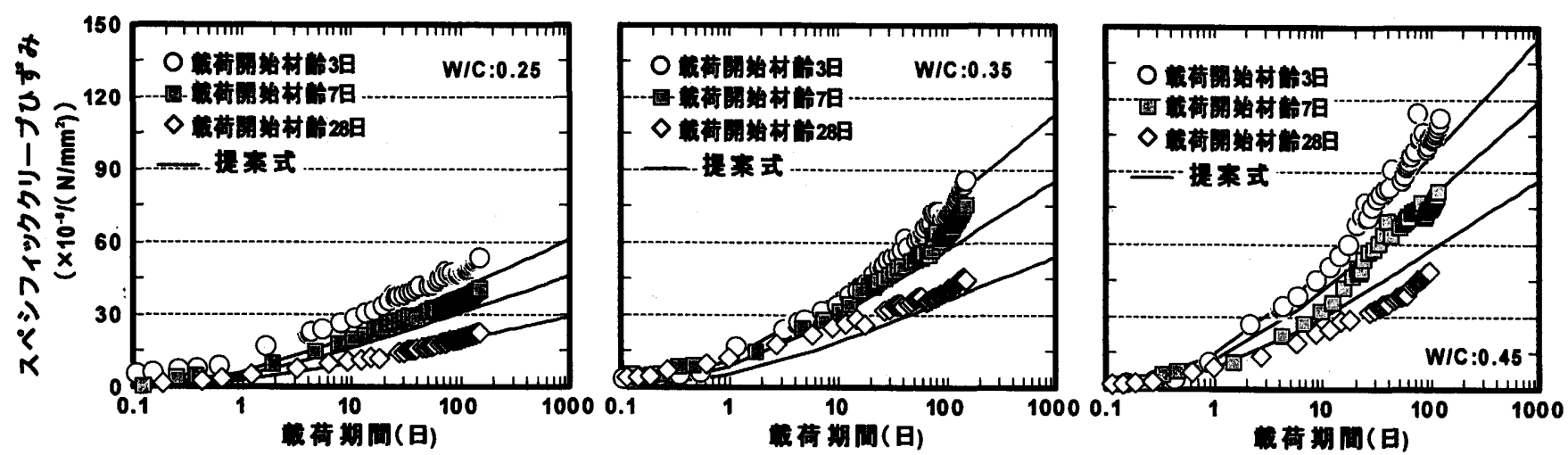

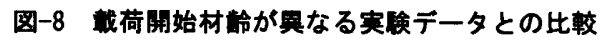

提案されているクリープひずみの予測式に含まれるパラメータは異 なっている。そのため, 収集したデータすべてを利用しているわけ ではなく，本提案式においては 1340，土木学会式では 1246 のデー 夕数を用いているが, CEB-FIP1990 式, ACI209 式においては, クリ ープひずみを算出するために必要な調合条件などが揃っていないた めに，それぞれ，596，286 のデータ数である。なお, 表-1に示すよ うに，各予测式には適用簀囲が定められており，これらの範囲を満 足するデータを用いて計算を行った。ただし，土木学会式において は体積表面積比の適用筑囲は除外し、計算を行った。
図中の○のプロットが普通ポルトランドセメント・混和材無混 入・天然骨材を使用したデータであり，田は普通ポルトランドセメ ント以外のセメントを使用しているものや混和材として高炬スラグ 微粉末, フライアッシュおよびシリカフュームを混入しているデー タである。この図によると，CEB-FIP 式においてはクリープひずみ の増大に伴い，過大評価する傾向にあり，さらに，ばらつきが大き くなっている。AC1209式においては全て過小評価する傾向にある。 土木学会式は比較的良く適合しているが，ひずみの増大にともない 過大評価する傾向が伺える。一方，本提案式は他の予測式と比較し
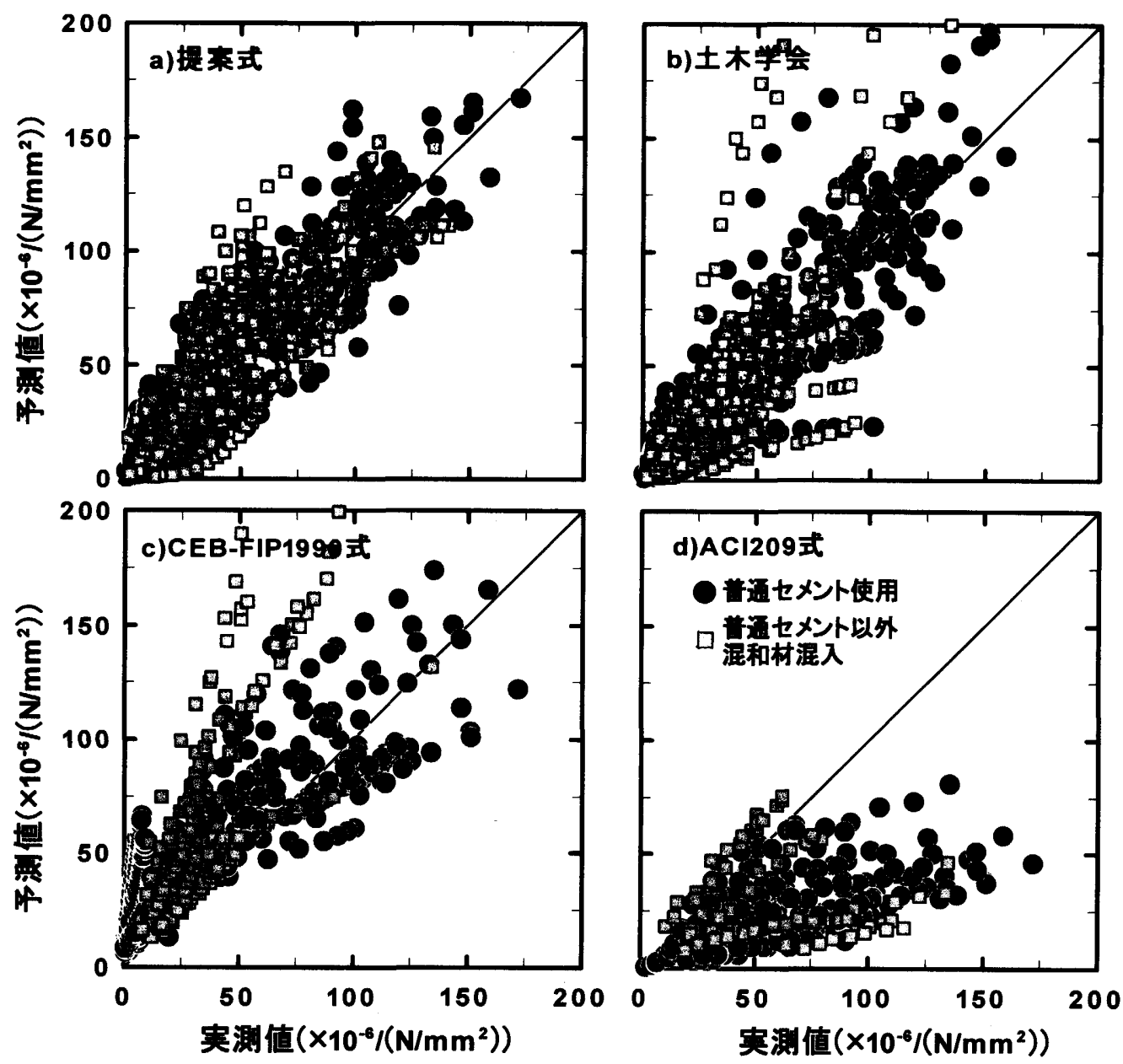

图-9 矛測值と实測值の比較 
て平均的に実験データを表すことができていることがわかる。これ らの予測式の精度について検討するために，実測值と予測値の差で ある残差の平均と分散を算出した。その結果を表-2 および図-10に 示す。平均が 0 に近く, 分散が小さい值を示しているものほど精度 が高いといえるが，これによると本論文で検討した実験データに対 しては, 残差の平均值は土木学会式が, 残差の分散は本提案式が最 も值が小さいことが分かる。

これらのことから，本提案式を用いることによって国内の材料を 使用したコンクリートのクリープひずみが予測可能であることが確 認できた。

\section{5. まとめ}

本論文では，国内の学会で公表されたクリープひずみの実験デー 夕を収集し，調合，載荷開始材齢，湿度および供試体寸法の影響を 考虑した Total Creepにおけるクリープひずみの予測式を提案した。 本提案式は, 時間関数を対数関数で表しており, 既往の予測式と比 較すると数式が简便である。既往の予測式と比較検討した結果, 本 提案式は普通強度から高強度の範囲までのコンクリートのクリープ

表-2 残盖の平均と分散

\begin{tabular}{|c|c|c|c|c|c|}
\hline & 残差 & 提家式 & 土木学会式 & CEB-FIP 式 & $\mathrm{ACI}$ 式 \\
\hline \multirow{3}{*}{$\begin{array}{c}\text { 普通 } \\
\text { セメント }\end{array}$} & 平均 & 6.35 & 1.67 & 16.29 & -34.98 \\
\hline & 分散 & 235.95 & 332.31 & 516.64 & 737.27 \\
\hline & 宁-多数 & 587 & 554 & 372 & 214 \\
\hline \multirow{3}{*}{$\begin{array}{l}\text { 普通 } \\
\text { セx年 } \\
\text { 以外 }\end{array}$} & 平均 & 4.33 & -0.45 & 25.41 & -25.79 \\
\hline & 分散 & 230.27 & 445.33 & 990.51 & 1096.95 \\
\hline & $\overline{\mathrm{j}}^{\circ}-$ 擞 & 753 & 692 & 224 & 72 \\
\hline
\end{tabular}
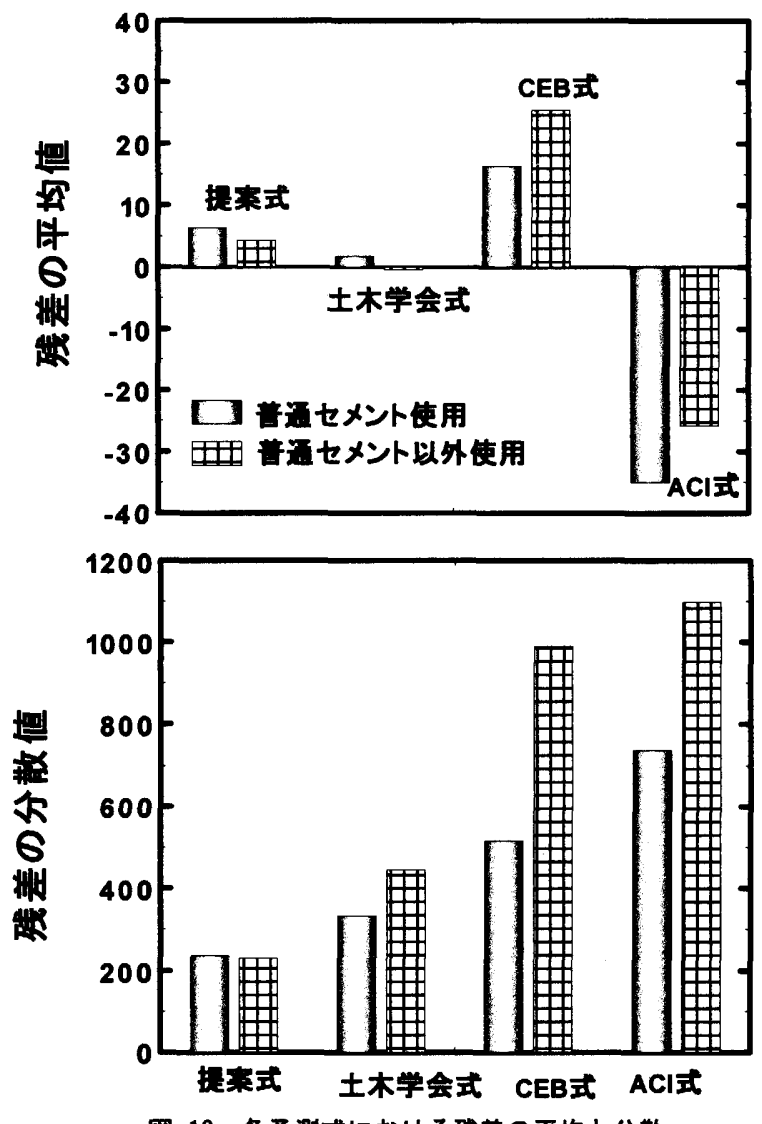

图-10 各予測式における残美の平均と分散
ひずみを既往の予測式と同等以上の精度で予測が可能であることが 確楒できた。

なお，本提案式は，構造物または部材に用いられるコンクリート のクリープひずみの平均値を表すことができる簡便な予測式であり， さらに精度の向上を図るためには，材料の種類に関する実験データ や体積表面積比に関する赛験データの蓄積が必要である。

碀辞

本研究の実施にあたりまして, 大分大学 修論生: 永松聡美氏, 卒 論生 : 岩下望美氏, 石本幸一氏(2004 年度)に多大のご協力を得まし た。また，本研究の調査は，日本建築学会材料施工委員会収縮ひび 割れ小委員会の活動の一環として実施したものであり，委員各位お よび貴重な実験データをご提供頂いた方々に紙面を借りて厚く謝意 を表します。

\section{考文献}

1）佐藤嘉昭，長期荷重を想定した実験一コンクリート構造物におけるクリ 一プと乾燥収縮一，コンクリート工学, Vol.39, No.9, pp.68-73, 2001

2) Neville, A.M., Dilger, W. H. and Brooks, J. J. : Creep of plain and structural concrete, $1^{\text {st }}$ Edition, Construction Press, 1983

3) COMITE EURO-INTERNATIONAL DU BETON : CEB-FIP Model Code 90, Thomas Telford, 1990

4) ACI Committee 209:Prediction of Creep, Shrinkage and Temperature Effects in Concrete Structures, 1982

5）土木学会、コンクリート標準示方書 [椿造性能照查編], 2002

6) 日本コンクリートエ学協会, コンクリート粠造物のクリープ及び収縕に よる時閆依存変形に関するシンポジウム, 2001

7) Bažant, Z.P. and Osman, E. : Double power law for basic creep of concrete, Materials and Structures, RILEM, Vol.9, No.49, pp.3-11, 1976

8) Ishai, O. : Elastic and inelastic behaviour of hardened mortar in torsion, Am Concrete, Inst. Spec. Publ., SP-9, Symp. on Creep of Concrete, pp. 65-94, 1964

9) Illston, J.M. : The components of strain in concrete under sustained compressive stress, Magazine of Concrete Research, Vol.17, No.37, pp.37-42, 1974

10) Rüsh, H., Jungwirth, D.J. and Hilsdorf, H. : Kritsche Sichtung der Verfahren zur Berücksichtigung der Einflusse Von Kriechen, Beton und Stahlbetonbau, 68 , pp.49-60,1973

11) Illston, J. M., Dinwoodie, J. M. and Smith, A. A. : Concrete, Timber and Metals the nature and behaviour of structural materials, VAN NOSTRAND REINHOLD COMPANY

12)永松懈也，佐藤嘉昭 : 水和の進行による影警が無視し得るとみなされる コンクリートの圧縮クリープ性状, 日本建築学会論文報告集, 第 340 号, pp.1-10, 1984

13）永松静也, 佐藤嘉昭, 竹田吉紹 : あらかじめ乾燥したコンクリートのク リープ性状および乾煰の程度を含んだクリープ関数，日本建学会䑳文報告 集 第 351 号, pp.12-21，1985

14) Bažant, Z.P. and Panula, L. : Practical prediction of time-dependent deformations of concrete, Part III drying creep, Materials and Structures(RILEM), Vol.11, No.65, pp.415-424, 1978

15) Brooks J.J. and Neville A.M. : Predicting log-term creep and shrinkage from short-term tests, Magazine of Concrete Research, 30, No.103, pp.51-61, 1978

16) 綾野克紀 : クリープの予测手法とその精度の現状, コンクリート工学, Vol.43, No.5, pp.51-55, 2005

17）阪田㥶次，綾野克紀，廣村浩：コンクリートのクリープひずみの予測式 の提案, コンクリート工学年次論文集, 第 10 巻, 第 2 号 pp.271-276, 1998

18）安田正雪, 桝田佳宽ほか 3 名 : 大型コンクリート柱部材の圧縮クリープ 性状, 日本建築学会大会学術講演梗概集, A-1 分冊, pp.551-512, 1991

19）山内崇，清原千鶴ほか 5 名：高強度コンクリートの圧綰クリープ特性, 日本建築学会研究報告, 九州支部, 第 $42 \cdot 1$, 楼造系, pp.53-57, 2003 